\title{
A Pandemic Review of Covid-19 Situation in Bangladesh
}

\section{Journal of Bioscience \& Biomedical Engineering}

Review Article

\section{Abdul Kader Mohiuddin}

Department of Pharmacy, Secretary and Treasurer, Dr. M. Nasirullah Memorial Trust, Tejgaon, Bangladesh

\author{
"Correspondence author \\ Abdul Kader Mohiuddin \\ Department of Pharmacy \\ Secretary and Treasurer \\ Dr. M. Nasirullah Memorial Trust \\ Tejgaon \\ Bangladesh
}

Submitted : 05 May 2020 ; Published : 28 May 2020

\begin{abstract}
COVID-19 has affected 212 countries around the world, killing more than 346,000 and infecting more than 5.5 million by May 25,2020. Bangladesh, a South Asian low-middle-income economy, has experienced a demographic and epidemiological transition with rapid urbanization and a gradual increase in life expectancy. It is the seventh most populous country in the world and population of the country is expected to be nearly double by 2050. The increasing burden of communicable diseases in Bangladesh can be attributable to rapid urbanization and nearly $50 \%$ of all slum dwellers of the country live in Dhaka division. In 2017, National Rapid Response Team of IEDCR investigated 26 incidents of disease outbreak. The joint survey of the Power and Participation Research Centre and BRAC Institute of Governance and Development reveals that per capita daily income of urban slum and rural poor drops by $80 \%$ due to present countrywide shutdown enforced by the government to halt the spread of Covid-19. 40\%-50\% of these population took loans to meet the daily expenses. However, the country has just 127,000 hospital beds, 91,000 of them in government-run hospitals. Researchers say, the country's economy is losing BDT 33 billion every day from its service and agriculture sectors during the nationwide shutdown.
\end{abstract}

Keywords: Domestic Violence During Lockdown; Healthcare Denial; Poor Adherence to Self-Quarantine; Natural Disasters amid Covid-19; Repatriation of Migrant Workers; Supply Chain Crisis

\section{Abbreviations}

IEDCR: Institute of Epidemiology, Disease Control and Research

BRAC: Bangladesh Rural Advancement Committee

\section{Introduction}

Notwithstanding the depressing state of major indicators such as negative export-import growth; significant revenue drop; shrinking private sector investment; rising un-performing loans documented in 2019 [1-16]. Bangladesh's government was optimistic that somehow the depressing trend of these indicators might be reversed. But this optimism has now been seriously dented with the severe onslaught of Covid-19. The decline in national and global demand for manufactured goods, particularly in the garment sector, risks creating unemployment and deepen poverty. The urban poor will be hardest hit while the number of additional poor will be higher in rural areas. The IEDCR was Bangladesh's only Institute with testing facilities for COVID-19 until March 26, when a second facility was granted testing rights. Centralized testing has not yet been able to respond effectively to the wave of suspected COVID-19 patients in these under-resourced public institutions. Amidst this global crisis, Bangladesh has been identified as one of the 25 most vulnerable countries to be affected by the fastspreading virus $[17,18]$. By 25. 04. 2020, it was confirmed in 63 out of 64 districts (Figure 1) [19]. The combined capacity of 19 corona-testing laboratories is around 5,000 samples per day, but in the last few days, authorities have conducted only 2,100 tests $[20,21]$. Unwillingness of the authorities concerned and bureaucratic complexities have indicated that the availability of a kit delays the detection of the novel coronavirus infection. Moreover, the government in Bangladesh has not so far sought to proactively limit transmission from primary cases to community [22]. 


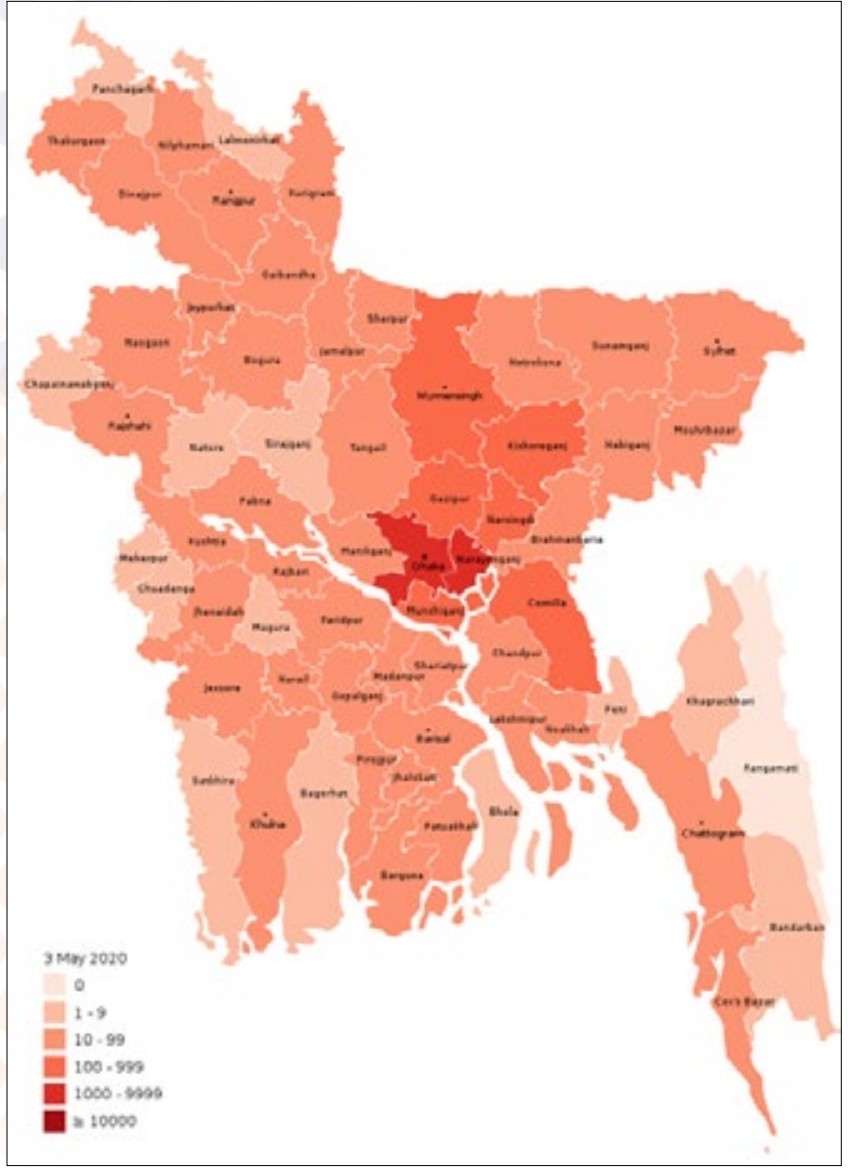

Figure 1: District wise COVID-19 Infected Cases in Bangladesh.

\section{Current State of Epidemiology}

More than $80 \%$ of the 33,610 coronavirus cases detected in Bangladesh have been reported in the Dhaka division and nearly $60 \%$ of them are in the capital, Dhaka [23, 24]. Around $68 \%$ of them are men while they comprise $73 \%$ of the dead, according IEDCR and experts are pointing 2 main reasons, outside exposure and hygiene practice [25]. An analysis of the coronavirus patients by age demonstrated that the highest proportion of the infected people $24 \%$ - were between 31 and 40 years, followed by $22 \%$ in the age bracket of $21-30$ years and $16 \%$ aged 41 to 50 years, according to IEDCR (Figure 2). Virologists have noted a lack of testing that would give a clearer picture of the true number of coronavirus infections. As expected, Number of new infections raised after the country has softened its restrictions on factories to pave the way for reopening despite the worsening COVID-19 situation in the country (Figure 3) [26]. Although, 8\% infected, no death was reported among the age bracket of 11-20 years (Figure 4).

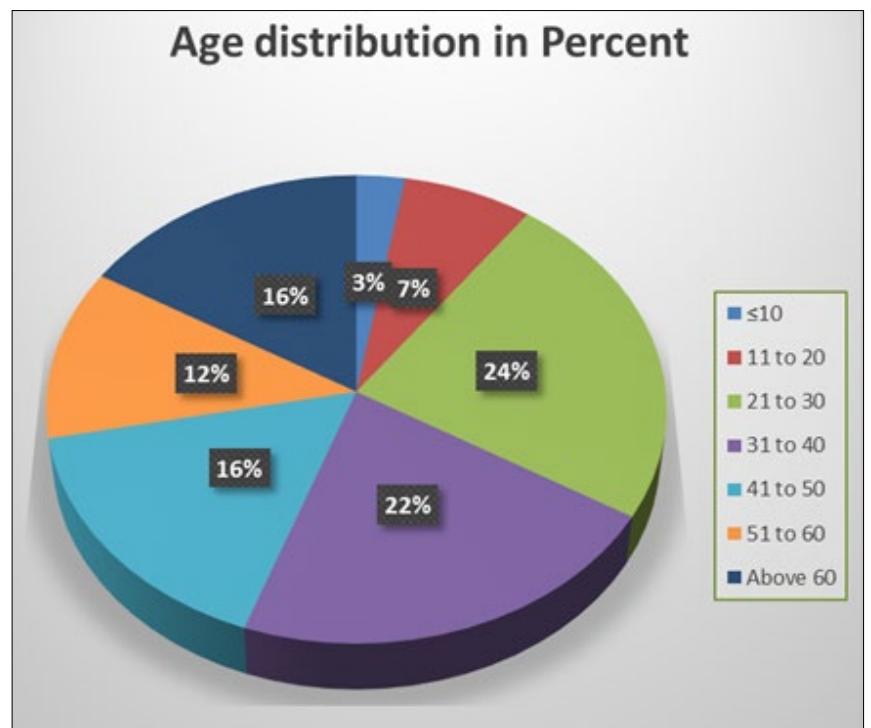

Figure 2: Age Distribution in Percent

Data from the Institute of Epidemiology, Disease Control and Research showed that $62 \%$ of the infected cases were aged between 21 and 50 years [27].

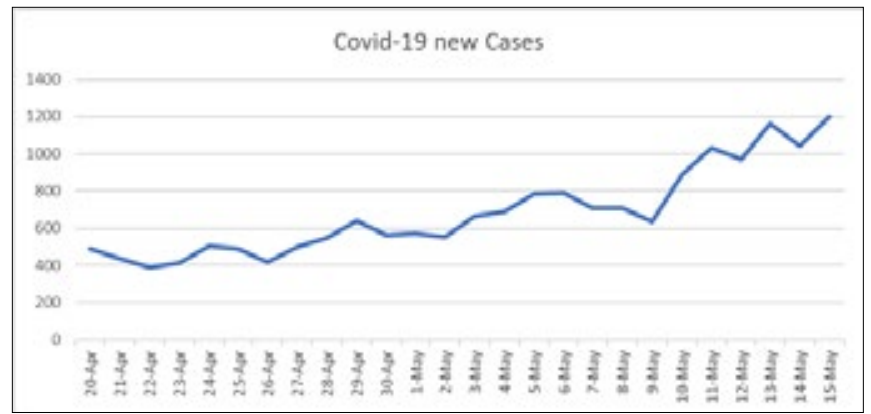

Figure 3: Covid-19 New Cases Detected in Bangladesh from 20-April to 15-May 2020

The curve was almost flat. This means the infection rate was not increasing among lockdown. Practically, number of tests conducted so far is too small not truly represents the actual situation. However, the curve showing a significant turn after May-8, when the lockdown is partially withdrawn.

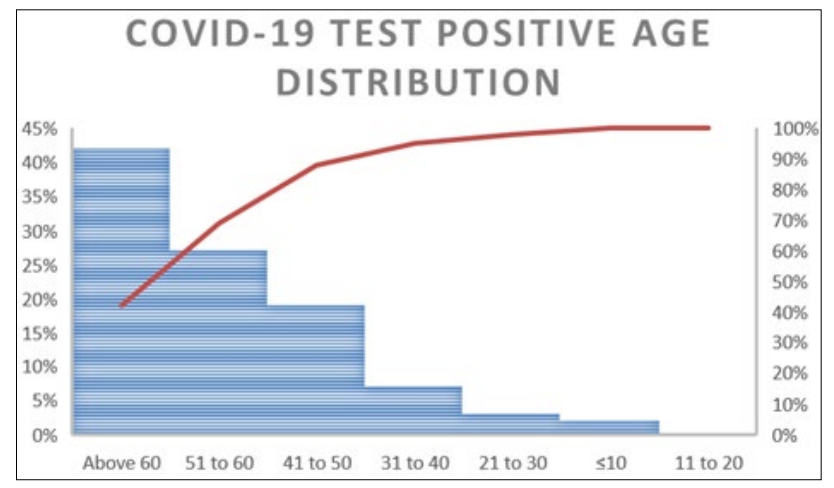

Figure 4: Covid-19 Test Positive Age Distribution among Bangladeshi Population 
According to IEDCR, highest death reported in patients above 60 and no death reported in the infected cases aged between 11 and 20 years.

\section{Present Hospital Situation with Covid-19 Patients}

Many patients with fever, cold and breathing problemswhich are also COVID-19 symptoms-have gone untreated as the hospitals in Dhaka are sending them to the IEDCR for coronavirus test [28]. Most hospitals are not in a position to provide doctors and other health associates with the personal protective equipment (PPE) like masks, gloves, and infected patients could walk into the hospital at any moment [29-35]. Many doctors are not providing services fearing the contagion and lab technicians are shunning workplaces, halting medical tests, according to the patients. In some cases, serious patients who are not affected by COVID-19, moved from one hospital to the other but could not receive treatment and finally died, the media reported. In another case, the doctor fled leaving the patient behind [36-40]. Doctors and other health professionals say they do not even have sufficient protective gear and the health care system cannot cope with the outbreak [41]. Experts believe that older people afflicted with coronavirus need the most ICU support [42]. The number of older persons in the country is over 0.8 million. In line with international standards, a 100-bed hospital should have at least five ICUs [43]. In reality, hospitals in Bangladesh have less than 1200 ICU beds (432 govt, 737 private) in total against a population of 161.4 million people [44]. There are reportedly 1,769 ventilators in Bangladesh at this moment or in the pipeline, which means an average of one ventilator for every 93,273 people [45]. Interestingly, Covid-19 is also producing large quantities of hazardous medical waste, with PPE used in hospitals being the main component $[46,47]$.

\section{Public Awareness Vs Attitude}

Most people are now aware in Bangladesh that the disease can happen to anyone and even cause death [48]. Although a nationwide BRAC survey (31 March-5 April 2020) says that almost 40 percent of respondents have no idea how to prevent the virus from becoming infected $[49,50]$. The shutdown, announced first on March 26, has already been extended fourth time to May 16th [51-53]. The government has discouraged movement after 6pm, instructing everyone to stay at home [54]. The people are fooling law enforcers by travelling from one district to another by mostly vehicles that transport goods [55]. Also, garment workers walk on the street demanding their due wages during the lockdown amid concerns over the outbreak in capital, Dhaka, on April 13, 2020 [56, 57]. Surprisingly, around 100,000 people attended a funeral gathering for a popular Muslim cleric, ignoring calls from different quarters to maintain physical distancing and hygiene [58-61]. Also, violence reported during this lockdown, where, 30 people were injured and one person's leg was cut off during the clash over establishing dominance [62-64]. Several other violations are also reported like unnecessary public gathering, gossiping, roaming without a purpose, staring at home under lockdown etc. in both print and online media, inside and outside the capital [65-71]. Decision-makers say "Chinese lockdown strategy" will not be fully applicable to Bangladesh because of poor socio-economic conditions for people and other factors (such as government capacity, support infrastructure, technology and medical facilities). This risk is compounded by thousands of Bangladeshi workers returning from COVID19-struck countries and poor adherence to self-quarantine recommendations due to limited education and monitoring mechanisms [72-75]. Although general holidays extended, the government has decided to allow businesspeople to keep shops and shopping malls open, considering Ramadan and Eid-ulFitr [76]. The number of shops with less than 15 employees in the country is 5.6 million. Around 12 million employees work at those shops [77]. So, community transmission may not be fully protected. However, Government employees will not be allowed to leave their workplaces on the occasion of the 2020 Eid-ul-Fitr, one of the religious festivals for Muslims. And also, inter-district public transport will remain closed during the period, according to the order of the cabinet division [78].

\section{Health Providers and Law Enforcers Got Infected}

According to The Directorate General Health Services' latest figures of registered physicians, there are 93,358 Bachelor of Medicine, Bachelor of Surgery (MBBS) doctors and 9,569 BDS doctors in the country [79, 80]. The last health bulletin published by the Health Ministry says that the country has only six doctors, nurses, and midwives for every 10,000 population [81]. Challenges to the country's already-overburdened healthcare system are being exacerbated by a string of COVID-19 cases among doctors. More than 600 doctors have been infected with Covid-19 so far, along with some thousands other allied health professionals, making up $11 \%$ of the total infections reported in the country. Besides infection, some 600-700 doctors are also in home or institutional quarantine [82-85]. The Public Service Commission, at the behest of the health ministry, began the process of recruiting 2,000 doctors and more than 5,000 nurses to combat the crisis on the frontlines [86, 87]. Around 10,000 members of Bangladesh's armed forces and more than 200,000 police officers and fire fighters are working to control the Covid-19 outbreak. More than thousand police officers have been placed in quarantine and close to 1900 of them have become infected, with more than hundred tested Covid-19 positive in 2nd April, 2020 alone [88-92]. However, finance ministry of the country declared incentive BDT 0.5 million to 5.0 million to government officials and employees working with life risk in the field including doctors, nurses, health workers, police, local administration [93].

\section{Trial of Unsilenced Drugs and Diagnostic Aids}

A group of Bangladeshi doctors of a private Bangladesh Medical College in Dhaka, claimed success after using Antiprotozoal medicine Ivermectin and Doxycycline antibiotic for coronavirus-19 infected patients [94, 95]. Earlier, some other hospitals tried hydroxychloroquine, controversial for its 
life-threatening heart rhythm problems and hepatotoxicity [96, 97]. some of the companies of Bangladesh has taken approval or started production of antiviral drugs like Favipiravir (Avigan ${ }^{\circledR}$, Japan) and Remdesivir and they are about to be used for the Covid-19 patients, although not authorized by WHO/ FDA for the same [98-100]. However, the government has issued a warning against using coronavirus antibody test kits without permission from the health authorities amid questions over the accuracy of results $[101,102]$.

Price Hike of the Daily Necessities and Natural Disasters amid Covid-19

Where income of the poor dropped by $80 \%$, the prices of essential commodities surged, adding to buyers' woes amid the COVID-19 crisis between March and April, 2020 [103]. The suffering of some 7 million slum dwellers around Dhaka, is multiplying due to lost earnings and price hikes of consumer goods [104]. Consumers alleged some unscrupulous traders have hiked the prices of commodities to make quick buck during Ramadan [105]. After the first case of coronavirus was confirmed in Bangladesh the very next day the highest court of the country had to 'direct' the government to take necessary steps to stop price hike of masks, hand wash, and sanitizers, or storing them to make extra profits later [106]. Nearly $35 \%$ of the country's total import is China based and prices of various disposable medical instruments (bouffant caps, shoe cover, medical clothing, test strips, surgical gauze and sponges, surgical gloves, bed sheet, lab test instruments, and diagnostic reagents) have been showing an upward trend due to decline in their shipment [107]. Although, Trading Corporation of Bangladesh launched open market sale of key essential items ahead of the fasting month of Ramadan, people queue/social distancing is rarely maintained there [108-110]. Syndicates are taking advantage of poor surveillance by government agencies to monitor prices. Increasing the demand for products which in turn is allowing many unscrupulous traders to increase prices two months ahead of Ramadan. This is increasing the scope for such traders to make more money through hoarding [111-113]. An opposite scenario is found with the farmers, as the prices of their produces have declined sharply for lack of marketing following the lockdown amid the outbreak [114117]. A massive stream of desert locusts may be heading towards Bangladesh and India passing over the Indian Ocean. This possible attack from the crop destroying insects may worsen the situation further [118]. Also, hailstorm, flood and other natural disasters are predicted for this year [119, 120]. All these can multiply the severity of crisis in a near future.

\section{Economic Crisis Among Pandemic Situation}

$80 \%$ of the country's export earnings are from RMG sector and include $13 \%$ to the GDP of the country. The major export destinations include the United States, U.K., Germany, France, and Italy [121-124]. Pressure to meet production deadlines from American and European garment brands and possible loss of business to competitors have prompted factory owners to reopen manufacturing units [125]. These crowds could emerge new vectors of the COVID-19 pandemic in Bangladesh.
Bangladesh has around 10.0 million workers overseas, with a majority in the Middle East and the US, UK, and Malaysia [126]. However, most Bangladeshi migrants work in West Asia, where declining oil prices have hit economies. Many will be forced out of their jobs and will have to return home to unemployment [127]. This is not surprising because slowdown in US and EU economies have had ripple effects in the Bangladesh economy. Meanwhile, banks were trying to come to terms with the Ministry of Finance directive of $6 \%$ and $9 \%$ caps to interest rates on deposits and loans; vulnerable asset quality; moribund capital markets; and a struggling microfinance sector as access to donor funds and bank financing become more competitive $[128,129]$. It is worth noting that in the last three months, private sector credit growth was already declining. Banks were experiencing an additional pressure in paying clients as money withdrawal was more than any normal time, out of fear of lockdown. The central bank has taken several initiatives to meet the liquidity crisis in the banking sector and overcome the current economic crisis [130]. However, Growth rate for Bangladesh, as projected by IMF, now stands at $2 \%$ for 2020 against $7.9 \%$ in 2019 [131]. Also, The GDP is expected to grow by $8 \%$ in FY2021, according to the ADB [132].

\section{The Country's Supply Chain at Risk}

57,500 tons of fresh fruits, 1,473 tons of onions, 475 tons of ginger, and 850 tons of garlic - in 2,500 containers - have remained stuck at the Chittagong Port yard till April 25, due to the slow delivery of goods amid the Covid-19 shutdown [133, 134]. Activities at Chittagong port have come to a standstill as the amount of import containers has exceeded the port's storage capacity due to slow delivery of goods. It may keep the ships waiting and it will increase the demurrage for importers. The number of containers at the port yard is increasing significantly since the importers are taking delivery of containers slowly as the country is going through lockdown [135-137]. As sales of fresh fruits decreased, importers are not releasing their consignments from the port causing huge congestion of freezer containers in the port. Product delivery from the port has declined due to the shortage of transport workers and vehicles, as well as slow revenue collection. Several importers expressed that they had brought in products amid a number of difficulties, but they were unable to receive deliveries due to the pandemic [138]. However, the CPA is trying to transfer some containers to privately-run Inland Container Depots (ICDs) known as "Off-dock" as an alternative measure to tackle the situation.

\section{Rising Domestic Violence and Psychiatric Illness}

Millions of people around the globe are stressed and nervous due to various associated reasons such as-- fear of being infected and losing loved ones, losing livelihoods, job insecurity, feelings of helplessness etc. Social distancing can cause long-term stress, anxiety, insecurity, low self-esteem, negativity, frustration and low motivation and overall downfall of mental health, which could become the main cause for physical illness [139, 140]. Violence against women and children is on the rise in Bangladesh amid the COVID-19 
lockdown due to lack of social activities and financial pressures are increasing rifts within families [141-143]. Violence against women is common in this country, especially against women who come from the impecunious sections of society. Rights activists say the lockdown has made women and children more vulnerable to domestic violence and abuse as many of them are confined to their homes with no outside support. According to a recent survey more than 4,700 women and 450 children were subjected to domestic violence in 27 out of 64 districts of Bangladesh in April, with more than 1,600 women and 420 children facing violence for the first time in their lives. More than $90 \%$ of the child victims were abused by their parents and relatives [144-147].

\section{Conclusion}

Since there is no vaccine and specific anti-viral drugs so far, public health measures are considered as an effective tool to mitigate the impact of the virus in the community. Besides the set-up of health care, institutional safeguard against COVID-19 infection during a pandemic attack is also important. A strong public health infrastructure that can constructively think for future preparedness, development and research toward emerging and re-emerging infectious diseases is compulsory. The method includes community engagement in which individuals develop the potential to avoid COVID-19 contacts and entail community-based approaches in which planners, employers and social activists can adopt strategies to protect vulnerable groups and the community from COVID-19 infection. However, Bangladesh isn't new to major international emergencies or disasters. Bangladesh's public and private sector leaders need to come together just to address the immediate threats to healthcare systems and the long-term effects on the country's economy.

\section{Future Recommendations}

Awareness campaign: The awareness campaigns should be relentlessly conducted by the government, private organizations and the media to involve community participation with mutual distancing to be effective. Deploying maximum manpower for the next few months to all those areas of the country where coronavirus infected patients have been identified and their families and all those who come in contact with the infected person. Adequate diagnosis and isolation/quarantine should be implemented in their own homes.

Co-ordination among Authorities: The National Disaster Council, under the leadership of Hon'ble Prime Minister, was formed on an urgent basis. As much work as it has been, the time has come to fold that whole work, to make it more integrated. The rationale for this is that other ministries are not yet fully integrated with the health ministry.

Promoting Telehealth: During epidemic outbreaks, home care is particularly effective when health authorities are not apparently safe to implement social distance systems and hospitals. Telehealth can provide convenient access to routine care in a congested hospital or in medical practice without the risk of exposure.

Distance Learning: For too long we have seen a disparaging and negative attitude towards online education from policymakers. Most teachers in Bangladesh do not have any experience of teaching online and are unfamiliar with online assessment techniques. They should be trained to provide distant learning.

Idea of Test-Booth: Samples can be collected by setting up coronavirus test booths without PPE like in South Korea in premises of medical colleges, districts, upazilas, union hospitals and community clinics, so that samples can be collected quickly anywhere in the country. Those who do not have experience in sample collection should be trained quickly through online / video conferencing.

Supporting the Helpless: Only those who can afford should pay and to deliver free food to all the poor and low-income people from door to door, by Army, Navy, BGB, Police, RAB, Ansar, Deputy Commissioner, UNO and public representatives. Then no one will get in trouble and no excuses will be left to get out of home. China, South Korea, Taiwan, Vietnam, India and Kerala have been successful with this method.

Separate Quarantines: A large number of express trains, steamers, high quality hotels, Ashulia Iztema grounds, stadiums, public and private hospital beds are currently unused in Bangladesh. All these train bogies, steamer cabins, hotel cabins, unused grounds can be converted into isolation centers for infected people. Isolation / quarantine cannot be $100 \%$ effective at home, as not everyone has more than one separate toilet and adequate room in their home.

Monitoring People from Abroad: All those who have entered Bangladesh recently from abroad through airports, land ports, seaports, railways and their families, or all those returning home should be tested for coronavirus and to be monitored accordingly.

Ensure More Test: Allowing all A-grade private hospitals to conduct rapid coronavirus testing and treatment and announcing reasonable/fixed test fees by the government. Services of other hospitals/clinics, which were closed due to fear of coronavirus, should be re-opened.

Provide More Medical Oxygen: According to WHO, most people with COVID-19 develop only mild or uncomplicated illness, while approximately $14 \%$ develop severe disease that requires hospitalization and oxygen support. Only a few hospitals, including Dhaka Medical College Hospital, Bangabandhu Sheikh Mujib Medical University, Sir Salimullah Medical College Hospital, Square Hospitals, Apollo Hospital and Anwer Khan Modern Medical College Hospital, have central oxygen supply facility. This facility should be increased.

A Larger Health Budget: At less than 1\% of GDP, government 
health spending in Bangladesh is among the lowest in the world. The WHO recommends allocating at least 5\% of a country's GDP and $15 \%$ of the total budget for the health sector. Government should spend additional resources directly on government doctors, drugs, hospitals and health centers and increase the allocation in education to ensure quality by recruiting qualified teachers, retaining them by providing incentives and ensuring better infrastructural facilities and resources.

Implement Lockdown until Crisis is Over: All government and private offices, educational institutions, garments, factories, except for the essential service providers, should be closed until the coronavirus infection is brought under control. When lifting restrictions, it is important to be able to track and deal with any side effects, which could possibly be an increase in cases after lifting the restrictions, which is why the nation has to be equipped to deal with that before it happens through testing and supply of protective gear. This may result in the crisis happening again; therefore, the nation needs to be prepared.

Ensure More Safety Measures: When buying drugs, food, raw markets, fruits and fish, guidelines should be disseminated for all who go out and bring these products home (money, clothing, packets, bags can also be infected with the virus).

Monitoring Comorbid Population: The prevalence of comorbidities in the COVID-19 patients including hypertension, cardiovascular diseases, diabetes mellitus, smoking, chronic obstructive pulmonary disease (COPD), malignancy, chronic kidney disease and obesity, may be risk factors for severe patients compared with non-severe patients. Everyone is susceptible to this virus, but the elderly and those with underlying diseases are more at risk of adverse outcomes. Given that COVID-19 has a relatively long incubation period and during this time, the infected person can transmit the virus without showing symptoms, it is strongly recommended that patients with chronic or underlying diseases avoid any close contact with other people in the community, especially in epidemic areas.

Boosting Immunity Campaign: To boost the immune system and preventing coronavirus, every person should consume ginger, cinnamon, cloves, sticky honey, black cumin, turmeric, triphala and tulsi, along with tea, consuming hot water and gargles twice or thrice every day and adding vitamin $\mathrm{C}$ or vitamin $\mathrm{C}$ twice a day.

\section{Employing More Allied Healthcare Associates:} Overburdened by patient loads, physicians have increasingly turned to pharmacists in US, UK, UAE, Australia for drug information, particularly within institutional settings. Pharmacy is taught in about 100 public and private universities in Bangladesh and about 8000 pharmacy students graduate every year. They can be more beneficial to the public if the good hospital and community practices are introduced properly.
Controlling the Concurrent Outbreaks: Intermittent rainfall, temperature variation, and higher humidity as a result of climate change are affecting the change in disease incidence. Along with Covid-19, the country should also get well prepared for the impending dengue season. There were more than 100,000 reported cases within the country in 2019 , so proper mosquito prevention should be everywhere.

Protect Victims of Domestic Violence: Voice should be raised against domestic violence along with concern development of victim shaming, lack of understanding of the cycle of abuse, social stigma, lack of knowledge and capability of supporting domestic violence victims at the community level etc. Steps should be taken with the aims to leverage the power of social media to influence constructive dialogue, increased awareness, empathy, call to action to end gender-based violence and child abuse.

Safe and Controlled Use of Disinfectants: Fire service, WASA, city corporations, municipalities at all divisional, district, Upazila, and union levels of the country have to spray disinfectant on the streets every day. All vehicles coming from outside should be sprayed keeping in mind that it could be detrimental (e.g. bleaching powder) for sensitive external organs like human eyes and face.

Prevent Repatriation: Support the Migrants and Ensure Safe Arrival: All the workers to be sent back by different employing countries, on arrival, will have to be placed under institutional quarantine, but the authorities may be hard put to accommodate them if they arrive at a time. So, their phased arrival will make things rather easy for the receiving authorities. Bangladesh defense should maintain a close liaison with the relevant ministry in the matters of post-arrival formalities and quarantining the repatriated workers. This is expected to make a difference. Also, foreign ministry should ask compensation for them, at an appropriate time, for the loss that Bangladesh will sustain in view of taking back its workers.

\section{Acknowledgement}

I'm thankful to Dr. Colin D. Rehm, Clinical Assistant Professor, Department of Epidemiology \& Population Health, and Alert Einstein College of Medicine, NY, USA for her precious time to review my literature and thoughtful suggestions. Also, I'm also grateful to seminar library of Faculty of Pharmacy, University of Dhaka and BANSDOC Library, Bangladesh for providing me books, journal and newsletters.

\section{References}

1. FE Report (2019a) ESCAP sees BD's positive trade growth in 2019. The Financial Express.

2. FE Report (2019b) Slower external trade may impact growth. The Financial Express.

3. Uddin AKMZ (2020a) Slowing exports stretching trade deficit. The Daily Star.

4. Khatun F (2020) Bangladesh Economy: Grappling with 
growing pains. The daily Star.

5. Byron RK (2019) Shrinking revenue: a growing worry. The Daily Star.

6. Parvez S (2020) Revenue shortfall can't stop stretching. The daily Star.

7. The Financial Express (2017) NBR tax revenue collection falls short of target. The Daily Star.

8. Senior Correspondent (2019) Bangladesh revenue growth slows to five-year low of $10.7 \mathrm{pc}$. bdnews24.com.

9. Bhuiyan AH (2019) Flashback 2019 Economy: Falling exports, slow pvt credit major weaknesses. The Financial Express.

10. Hasan M (2019a) Private sector credit growth falls further owing to liquidity crisis. Dhaka Tribune/Business.

11. Uddin AKMZ (2020b) Why is private sector credit growth sinking? The Daily Star.

12. TBS Report (2019) 'The financial sector could be at risk of collapse'. The Business Standard/Banking.

13. Hasan M (2019b) NPLs rise by Tk3863 crore in 3 months. DhakaTribune/Business.

14. Islam S (2019a) Volume of NPL up 24pc in Q3. The Financial Express.

15. Islam S (2019b) NPL volume swells to Tk 939.11 billion. The Financial Express.

16. Hasan M (2019c) Looking back 2019: Nothing tames bad loans. DhakaTribune/Business.

17. Tajmim T (2020a) Covid-19 cases cross 200 since March, death toll hits 20. The Business Standard.

18. Tribune Report (2020) US embassy: Bangladesh among 25 countries at risk of coronavirus. DhakaTribune.

19. Dhar B (2020) Coronavirus: Rangamati remains only district to report zero infection. Dhaka Tribune.

20. UNB News (2020a) 16 more testing labs soon: Health Minister. UNB.

21. Sakib SMN (2020a) Bangladesh: Low COVID-19 testing rate raises concerns.

22. Mohiuddin AK (2020) Covid-19 Situation in Bangladesh.

23. The Financial Express (2020a) General holidays extended further till May 16. National.

24. Noman M (2020a) Half the country's Covid-19 infection in Dhaka city alone. The Business Standard.

25. The Financial Express (2020b) More men than women dying in BD from coronavirus. UNB/National.

26. Olukoga O (2020) Bangladesh extends COVID-19 lockdown, softens restrictions for factories. NNN News Nigeria.

27. Maswood MH (2020) Young, working-age people mostly infected with COVID-19 in Bangladesh. NEWAGE/ Bangladesh.

28. Masum O (2020a) Dhaka hospitals turning away patients with fever, cold needing coronavirus tests. bdnews24.com.

29. Ahmed I, Liton S (2020a) Does Bangladesh have enough ventilators? The answer is no. The Business Standard.

30. The Financial Express (2020c) Most hospitals not in position to provide nurses PPE. UNB/National.

31. Tithila KK (2020) Coronavirus: Inadequate protective gear leaves Bangladesh health workers at high risk. DhakaTribune.
32. Adhikary TS, Islam R, Hasan R (2020) Healthcare Professionals: On the front line, true to their oath. The Daily Star.

33. Star Online Report (2020a) Poor supply of PPE worries doctors. The daily Star.

34. Staff Correspondent (2020a) Doctors, nurses and staff dangerously exposed. The Daily Star.

35. Bosu S (2020) Doctors, caregivers unguarded for scanty protective gears. The independent/Bangladesh.

36. Staff Correspondent (2020b) Health minister vows to punish private hospitals for turning away patients. bdnews24.com.

37. Islam Z, Mollah S (2020) Admission to Hospitals: Patients left in quandary. The Daily Star.

38. Akhter F (2020) COVID-19 and healthcare denial. Newage Opinion.

39. UNB News (2020b) DU student 'denied treatment by hospitals' dies. The Financial Express/National.

40. UNB News (2020b) Coronavirus: 565 doctors infected in Bangladesh. UNB.

41. Chowdhury T (2020a) Poor Bangladeshis being turned away from hospitals. Al Jazeera America News/ Bangladesh.

42. Liu K, Chen Y, Lin R, Han K (2020) Clinical features of COVID-19 in elderly patients: A comparison with young and middle-aged patients. Journal of Infection.

43. Tajmim T (2020b) Bangladesh has only 29 ICU beds to fight coronavirus! The Business standard.

44. Rungta N, Zirpe KG, Dixit SB, Mehta Y, Chaudhry D, et al. (2020) Indian Society of Critical Care Medicine Experts Committee Consensus Statement on ICU Planning and Designing, 2020. Indian journal of critical care medicine: peer-reviewed, official publication of Indian Society of Critical Care Medicine 24: S43-S60.

45. Save the Children (2020) COVID-19: Bangladesh has less than 2,000 ventilators serving a population of $165 \mathrm{~m}$, warns Save the Children. Press Release.

46. Razzak MA (2020) Can Bangladesh cope with covid-19 medical waste? The daily Star/Opinion.

47. Hossain I (2020) Amid COVID-19 pandemic, biomedical waste turning more hazardous. UNB News.

48. Hasan K (2020a) Healthcare professionals now face the coronavirus wrath. DhakaTribune.

49. Rahman MR (2020) Real Action Needed To Prevent Corona: Bangladesh Perspective. Bangladesh Journal of Infectious Diseases.

50. Rahman S, Illius S (2020) Supply chain at risk. The Business standard/Trade.

51. BRAC Bangladesh (2020) Rapid Perception Survey on COVID19 Awareness and Economic Impact. https://reliefweb.int/sites/reliefweb.int/files/resources/ Perception-Survey-Covid19.pdf

52. BRAC Institute of Governance \& Development (2020) Phase II Media Tracking of Domestic Violence, Bangladesh. Rapid Research Response to Covid-19, Series: Gender. https://bigd.bracu.ac.bd/wp-content/ uploads/2020/05/Media-Tracking-of-DV_Phase-II.pdf

53. Opu MH (2020) In Pictures: The effects of coronavirus 
lockdown in Bangladesh. Aljazeera.

54. Shawon AA, Mamun S (2020) Bangladesh likely to extend shutdown until. Dhaka Tribune.

55. TBS Report (2020a) General holidays likely to be further extended till May 16. The Business Standard/Covid-19 in Bangladesh.

56. Ahmed S, Talukcar K (2020b) Lax lockdown fails to contain coronavirus spread in Bangladesh. bdnews.

57. Reuters Dhaka (2020a) Bangladesh textile wage protest. The Telegraph, India/World.

58. Kamruzzaman M (2020) Bangladesh: Massive funeral for cleric amid lockdown. Anadolu Agency/World, Asia - Pacific.

59. Mahmud A, Garcia J (2020a) 100,000 people gather for funeral in Bangladesh, defying coronavirus lockdown.

60. Ramachandran S (2020) The COVID-19 Catastrophe in Bangladesh. The diplomat/South Asia.

61. Wyatt T (2020) Coronavirus: More than 100,000 defy lockdown and gather for funeral in Bangladesh.

62. TBS Report (2020b) Two groups clash in Brahmanbaria violating lockdown. The Business Standard.

63. TBS Report (2020c) Man, who lost leg during clash in Brahmanbaria, dies at DMCH. The Business Standard.

64. Staff Correspondent (2020c) UP chairman among 2 held over rally with severed leg. The daily Observer/ Countryside.

65. Chowdhury Z (2020b) City building 'locked down' in name, but not in reality. The Business Standard.

66. Chowdhury Z (2020c) Dhaka, Narayanganj clusters locked down. The Business Standard.

67. NEWAGE (2020) Narayanganj lockdown not fully implemented. Bangladesh.

68. Mahmud I, Rashid M (2020b) Infection keeps rising in Bangladesh as people defy lockdown rules. NEWAGE/ Bangladesh.

69. Editorial Desk (2020) Lockdown is a must to contain coronavirus. e-Prothom Alo.

70. Abdullah M (2020) Coronavirus: Call for strict measures as people flout lockdown. Dhaka Tribune/Coronavirus.

71. Roy R (2020) Covid-19: National lockdown won't work alone. The Financial Express/Views.

72. Monjur M, Hassan M (2020) Early phases of COVID-19 management in a low-income country: Bangladesh. Infection Control \& Hospital Epidemiology 1:1.

73. AFP Singapore (2020) Bangladeshi workers live in fear as virus hits Singapore dorms. Dhaka Tribune/World.

74. Uttom S (2020) Bangladesh asked to take back thousands of migrant workers. Union of Catholic Asian News/ Bangladesh.

75. TBS Report (2020d) Bangladesh PM offers big aid for workers, poor over coronavirus. The business Standard/ Bangladesh.

76. The Financial Express (2020d) Shops, shopping malls to remain open till $5 \mathrm{pm}$. National.

77. Noman M (2020b) Covid-19 fallout: 56 lakh shop owners feel the pinch. The business Standard/ Covid-19 in Bangladesh.

78. News Desk (2020) Govt employees cannot leave workplace during Eid holiday. risingbd.com.

79. Debnath B (2020) 54 Apollo staff on quarantine after doctor who visited her Covid-19 uncle also gets infected. The Business Standard/Covid-19 in Bangladesh.

80. Debnath B, Tajmim T (2020) Doctors, nurses getting sick: Protective gear, curbs on non-essential services can save lives. The Business Standard/Covid-19 in Bangladesh.

81. UNB News (2020c) Coronavirus: Over 600 Bangladeshi doctors infected. UNB.

82. Independent Online/UNB (2020) Coronavirus: Doctor, 3 nurses in Sunamganj quarantine. The Independent/Metro.

83. Star Online Report (2020b) 500 doctors infected with Covid-19: Bangladesh Doctors' Foundation. The daily Star.

84. Star Online Report (2020c) 9 doctors among 27 hospital staff sent to home quarantine in Mymensingh. The Daily Star.

85. Sakib SMN (2020b) Bangladesh: 11\% COVID-19 cases among health workers. ANADOLU Agency/World, Asia - Pacific, Latest on coronavirus outbreak.

86. Masum O (2020b) Bangladesh COVID-19 tests hampered by scarcity of medical technologists. Bdnews24.com.

87. Kamol E (2020) Bangladesh govt to recruit 2,000 docs, 6,000 nurses immediately. NEWAGE/ Bangladesh.

88. Sakib SMN (2020c) Police in Bangladesh at great risk from pandemic. ANADOLU Agency/Asia - Pacific.

89. Sumon S (2020) Coronavirus lockdown police officers in Bangladesh get infected. Arab News/Home.

90. Star Online Report (2020d) 113 police personnel test Covid-19 positive in in last 24 hours. The Daily Star.

91. UNB News (2020d) Coronavirus: 9 firefighters test positive. UNB.

92. Prothom Alo English Desk (2020) COVID-19: 1,878 policemen infected in Bangladesh. en.prothomalo.com.

93. Staff Correspondent (2020d) Corona infected govt employees to get Tk 10 lakhs. Daily Bangladesh/National.

94. Staff Correspondent (2020e) Doctors claim success in corona treatment. The Daily Sun.

95. Masum O (2020c) Does ivermectin work against COVID-19? Some say yes. bdnews24.com.

96. Tajmim T (2020c) Bangladesh recommends controversial drugs for Covid-19 treatment. The Business Standard/ Covid-19 in Bangladesh.

97. Staff Correspondent (2020f) No bar on export of hydroxychloroquine: commerce ministry. NEWAGE/ Business.

98. AFP Tokyo (2020) Antiviral Avigan being tested for coronavirus patients. NEWAGE/Health.

99. TBS Report (2020e) Bangladesh likely to start using Remdesivir by May 20, vaccine trial starts in June. The Business Standard/Health.

100. Reuters (2020b) Bangladesh's Beximco to begin producing experimental COVID-19 drug remdesivir. Bdnews24. com/Business.

101.Alif A (2020a) Rapid Test kits: Boon or bane? Dhaka Tribune/coronavirus.

102.UNB News (2020e) Unauthorised coronavirus testing kits can't be used: Ministry. UNB. 
103. Staff Reporter Dhaka (2020) Daily essentials see price hikes amid COVID-19 lockdown. The Independent/ Business.

104. Hasan MR (2020b) Amid Covid-19 Hunger Fear Mounts in Bangladesh. Inter Press Service.

105.The Financial Express (2020e) Ginger, garlic witness abnormal price hike in capital. Trade.

106. Saha KK (2020) Pandemic coronavirus and price hike in medical items. The Asian Age/Editorial.

107. Bhuiyan AH (2020) Coronavirus: Prices of disposable medical items rising. The Financial Express/Trade.

108. TBS Report (2020f) Buyers crowd TCB sales centres amid Covid-19 concerns. The Business Standard/Covid-19 in Bangladesh.

109.FE Report (2020) TCB starts selling Ramadan essentials. The Financial Express/Trade.

110. Malay Mail (2020) Bangladesh shuts down villages after tens of thousands attend cleric's funeral. World.

111. Staff Correspondent (2020g) Government to monitor commodity costs to check price hikes. NEWAGE Bangladesh.

112. Staff Correspondent (2020h) Prices of Ramadan essentials rise. NEWAGE Business.

113. Karim R (2020a) Intel agency warns against Ramadan price hike. The Financial Express/Trade.

114. Mannan MA (2020) Coronavirus: Jashore farmers take the hit for falling vegetable prices. UNB/Special.

115. Shuvo M (2019) Farmers lose, millers gain. The Daily Star.

116. Wardad Y (2020) Farmers suffer for low demand, supply crunch. The Financial Express/Trade.

117. Mansur AH (2020) Taming coronavirus rampage: Ensuring food security during pandemic. The Daily Star/ Business.

118. Al Amin M (2020) Bad to worse: Looming locust attack amid coronavirus panic. DhakaTribune/Bangladesh.

119. Staff Correspondent (2020i) '4 more disasters this month'. Daily Bangladesh/National.

120.Kelly M (2020) Robust storms threaten flooding, strong winds over India and Bangladesh. Accu Weather/Severe Weather.

121.Aslam J (2020) Bangladesh reopens 600 apparel factories despite virus risk. News.

122.Kumar A (2020) Will the Pandemic Derail Bangladesh's Economic Growth? The Diplomet.

123. Hossain MA (2019) The Procedure of Cash Incentive and Its Role in the RMG Sector in Bangladesh: Evidence from Bangladesh. SSRN Electronic Journal.

124.Munni M (2018) Germany now top export destination of BD garments. The Financial Express.

125.Ellis-Petersen H, Ahmed R (2020) Bangladesh garment factories reopen despite coronavirus threat to workers. The Guardian/ Human rights in focus Bangladesh.

126. Amit S (2020) Coronavirus and the Bangladesh economy: Navigating the Black Swan event of 2020. Dhaka Tribune.

127. South Asia Economic Focus (2020) The Cursed Blessing of Public Banks.

128. The Financial Express (2020f) The challenge of executing single-digit interest rates. Views.

129. Hossin MS, Rahman MA (2020) Interest Rate Risk Management in Public Sector Bank of Bangladesh: With Special Reference to Sonali Bank Limited. Journal of Management, Economics, and Industrial Organization 2020: 01-21.

130.Hasan M (2020d) Bailout package: Banks' liquidity crisis to hinder implementation. DhakaTribune.

131. Mahmood M (2020) The global economy in 2020: Grim outlook. The Financial Express/Views.

132. The Financial Express (2020g) BD economy expected to remain strong: ADB. Economy.

133. Chowdhury SH (2020d) 2,500 containers of Ramadan goods await delivery at Chattogram Port. The Business Standard/Trade.

134. Karim N (2020b) It is imperative to ease port congestions for smooth trade. The daily Observer/OP-ED.

135. Hussain A (2020) Delivery on limited scale may trigger container congestion at Chittagong port. DhakaTribune.

136. The Financial Express (2020h) Chittagong port should clear the gluts. Editorial.

137.TBS Report (2020g) Coordination meeting held to mitigate container gridlock in Ctg port. The Business Standard/Trade.

138. Chowdhury SH (2020e) Supply disruption to push up prices of Ramadan essentials. The Business Standard/ Markets.

139. Shah P (2020) Psychological well-being: A challenge in Covid-19 regime. The Financial Express/Views.

140. Riyasad N (2020) COVID-19 and mental health around the world. NEWAGE/Youth.

141.Jahid A (2020) COVID-19 and domestic violence. NEWAGE/Opinion.

142. Hasan F (2020e) Addressing the rise in domestic violence during lockdown. The Daily Star.

143. Asha A (2020) Violence against women continues unabated. The Independent/ Bangladesh.

144. Alif A (2020b) MJF: 4,249 women subjected to domestic violence during the lockdown.

145. Welle D (2020) COVID-19 lockdown increases domestic violence in Bangladesh. taiwannews.com.

146.TBS Report (2020h) 4700 women, children abused in families during April lockdown. The Business Standard/ Bangladesh.

147.Hasan S (2020c) Coronavirus: Banks under pressure to pay clients. UNB.

Copyright: (C2020 Abdul Kader Mohiuddin. This is an open-access article distributed under the terms of the Creative Commons Attribution License, which permits unrestricted use, distribution, and reproduction in any medium, provided the original author and source are credited. 